\title{
3D high throughput screening and profiling of embryoid bodies in thermoformed microwell plates
}

Citation for published version (APA):

Vrij, E. J., Espinoza, S., Heilig, M., Kolew, A., Schneider, M., van Blitterswijk, C. A., Truckenmuller, R. K., \& Rivron, N. C. (2016). 3D high throughput screening and profiling of embryoid bodies in thermoformed microwell plates. Lab on A Chip, 16(4), 734-742. https://doi.org/10.1039/c5lc01499a

Document status and date:

Published: 01/01/2016

DOI:

10.1039/c5lc01499a

Document Version:

Publisher's PDF, also known as Version of record

Document license:

Taverne

Please check the document version of this publication:

- A submitted manuscript is the version of the article upon submission and before peer-review. There can be important differences between the submitted version and the official published version of record.

People interested in the research are advised to contact the author for the final version of the publication, or visit the DOI to the publisher's website.

- The final author version and the galley proof are versions of the publication after peer review.

- The final published version features the final layout of the paper including the volume, issue and page numbers.

Link to publication

\footnotetext{
General rights rights.

- You may freely distribute the URL identifying the publication in the public portal. please follow below link for the End User Agreement:

www.umlib.nl/taverne-license

Take down policy

If you believe that this document breaches copyright please contact us at:

repository@maastrichtuniversity.nl

providing details and we will investigate your claim.
}

Copyright and moral rights for the publications made accessible in the public portal are retained by the authors and/or other copyright owners and it is a condition of accessing publications that users recognise and abide by the legal requirements associated with these

- Users may download and print one copy of any publication from the public portal for the purpose of private study or research.

- You may not further distribute the material or use it for any profit-making activity or commercial gain

If the publication is distributed under the terms of Article $25 \mathrm{fa}$ of the Dutch Copyright Act, indicated by the "Taverne" license above, 


\title{
Lab on a Chip
}

CrossMark $<$ click for updates

Cite this: Lab Chip, 2016, 16, 734

Received 7th December 2015, Accepted 8th January 2016

DOI: 10.1039/c5lc01499a

www.rsc.org/loc

\section{D high throughput screening and profiling of embryoid bodies in thermoformed microwell platestt}

\author{
E. J. Vrij, ${ }^{\text {ab }}$ S. Espinoza, ${ }^{\text {be }}$ M. Heilig, ${ }^{c}$ A. Kolew, ${ }^{c}$ M. Schneider, ${ }^{c}$ \\ C. A. van Blitterswijk, ${ }^{\text {ab }}$ R. K. Truckenmüller ${ }^{\text {ab }}$ and N. C. Rivron*abd
}

\begin{abstract}
3D organoids using stem cells to study development and disease are now widespread. These models are powerful to mimic in vivo situations but are currently associated with high variability and low throughput. For biomedical research, platforms are thus necessary to increase reproducibility and allow highthroughput screens (HTS). Here, we introduce a microwell platform, integrated in standard culture plates, for functional HTS. Using micro-thermoforming, we form round-bottom microwell arrays from optically clear cyclic olefin polymer films, and assemble them with bottom-less 96 -well plates. We show that embryonic stem cells aggregate faster and more reproducibly (centricity, circularity) as compared to a stateof-the-art microwell array. We then run a screen of a chemical library to direct differentiation into primitive endoderm (PrE) and, using on-chip high content imaging $(\mathrm{HCl})$, we identify molecules, including regulators of the cAMP pathway, regulating tissue size, morphology and PrE gene activity. We propose that this platform will benefit to the systematic study of organogenesis in vitro.
\end{abstract}

\section{Introduction}

In vivo, cells reside within $3 \mathrm{D}$ environments, which create specific interactions that are not necessarily replicated in conventional (2D) cell culture. However, many cell types aggregate into $3 \mathrm{D}$ clusters, which better recapitulate structural organizations and biological functions. ${ }^{1}$ Embryonic stem (ES) cells aggregate into embryoid bodies (EBs) with the intrinsic capacity to recapitulate development and form organ models in vitro, including the gut, ${ }^{2}$ the eye ${ }^{3}$ and the brain. ${ }^{4,5}$ These organoids form upon sequential exposure to combinations of soluble factors that orchestrate proliferation, differentiation and morphogenesis. Such models are important to understand organ

\footnotetext{
${ }^{a}$ Merln Institute for Technology-Inspired Regenerative Medicine, Maastricht University, Maastricht, The Netherlands. E-mail: erikvrij@gmail.com, nicolasrivron@gmail.com

${ }^{b}$ MIRA - Institute for Biomedical Technology and Technical Medicine - University of Twente, Enschede, The Netherlands

${ }^{c}$ Institute of Microstructure Technology, Karlsruhe Institute of Technology (KIT), Eggenstein-Leopoldshafen, Germany

${ }^{d}$ Hubrecht Institute for Developmental Biology and Stem Cells Research, Utrecht, The Netherlands

${ }^{e}$ Fachbereich Physikalische Technik, Münster University of Applied Sciences, Steinfurt, Germany

$\dagger$ Electronic supplementary information (ESI) available. See DOI: 10.1039/ c5lc01499a

\$ Conflict of interest statement: Roman Truckenmüller is a founder of the company 300MICRONS GmbH, which develops micro-thermoformed products and technologies.
}

development and disease and, in the context of drug screens, to study of intermediate complexity between 2D culture and animal models. ${ }^{6,7}$ However, they are currently produced at a low throughput and with a low efficiency. There is thus a need for platforms increasing control and throughput while allowing direct on-chip measurements.

EBs are classically and still widely formed using the hanging drop method or round-bottom 96 well plates (96 wps). Evolutions of these culture techniques aim at decreasing the complexity of manipulations while increasing the reproducibility and throughput. In that context, laboratories working at the interface of microfabrication and cell-biology developed non-adhesive microwell arrays to spatially confine small, defined numbers of cells and control aggregation. Microwell arrays can be formed by hot embossing of polystyrene, ${ }^{8,9}$ replica molding of polydimethylsiloxane ${ }^{10,11}$ or hydrogels ${ }^{12-14}$ or micro-thermoforming. ${ }^{15}$ Of special interest for organoid systems, microwell arrays also preserve control over culture conditions (medium refreshment, substrate interaction, sequential addition of soluble factors) while allowing for active monitoring over increased number of replicates. Microwell platforms require high resolution microwells, high number of microwells per well, high number of conditions per plate, uniform cell seeding, easy harvesting of aggregates, compatibility with liquid handling systems and automated microscopes, and potential for manufacturing.

Here, we propose a micro-thermoformed microwell platform for the formation, screening and automated imaging of 
organoids. Micro-thermoforming of thermoplastic films ${ }^{16}$ is a method applicable to numerous materials, which bridges length scales and allows surface pre-modifications. ${ }^{17-19}$ An important benefit of micro-thermoforming over, for example, hot embossing is that it permits large-area high-precision forming of microwells with a very thin bottom (below 10 micrometers), thus enabling reproducible, high-magnification microscopy. The platform we present is based on a standard 96 wp to maximize the compatibility with established instruments, such as automated liquid-handling and imaging systems. We validated its potential for HTS using a library of small molecules classified as kinase inhibitors. Via HCI, we extracted features of cellular proliferation, gene activity, tissue size and morphology and assessed the functions of these small molecules in the context of primitive endoderm differentiation.

\section{Results}

Fabrication of thermoformed microwell screening plate

The platform consists of a bottomless $96 \mathrm{wp}$ mounted with a thermoformed Cyclic Olefin coPolymer (COP) film $(50 \mu \mathrm{m})$ imprinted with 96 microwell arrays. COP is a thermoplastic material with superior optical properties for fluorescent imaging as compared to polystyrene. It has low turbidity (haze value $<0.1 \%$ ) and low wavelength dispersion in the visible and near-UV spectrum. Additionally, the non-polar surface minimizes cellular adhesion. ${ }^{20}$ Microwells were microthermoformed all at once by a negative free-forming process. COP films were heated up to their rubber-elastic state by contact with the mold and then stretched into the evacuated mold recesses by pressurized nitrogen (Fig. 1a). Depending on the COP material and the location on the plate this yielded microwells with a depth of approximately $260 \mu \mathrm{m}$ (Fig. 1b) and an inner diameter of about $300 \mu \mathrm{m}$ (Fig. 1c). The microwells are hemispherical, which should improve cell aggregation.

The thermoformed films had lateral dimensions equivalent to that of a full $96 \mathrm{wp}$. They were aligned and pressure bonded to bottomless 96 wps by inserting a cytocompatible double-sided tape (acrylic elastomer, Fig. 1d). The $96 \mathrm{wp}$, the film and the tape, with punched holes aligned with the wells of the plate, constitute the full platform. Each well of the $96 \mathrm{wp}$ contains an array of 144 microwells constituted in a $12 \times 12$ grid aligned to the center of the well (Fig. 1e). After sterilization with ethanol, the platform was used by simply dispensing a cell suspension into the wells of the 96 wp.

\section{ESC aggregation kinetics}

COP is described as a low-adherent material for cells. ${ }^{20}$ When mouse ES cells were seeded within the microwells, they spontaneously aggregated into EBs. However, partial cell adhesion a Micro-thermoforming process
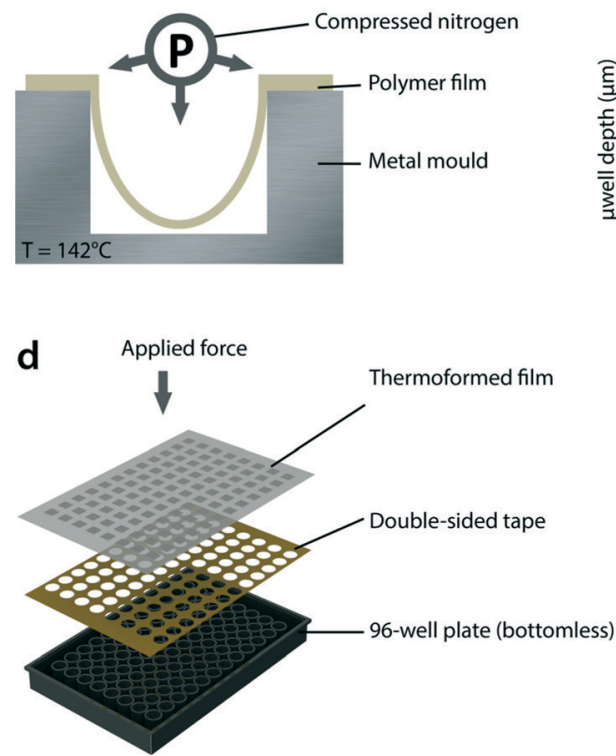

b

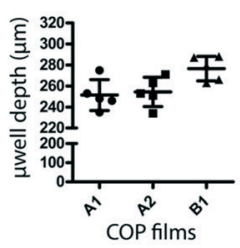

e
C

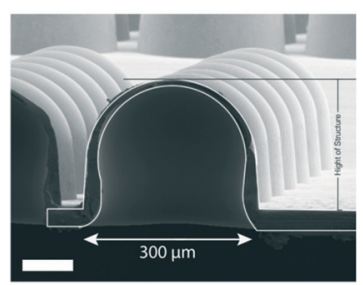

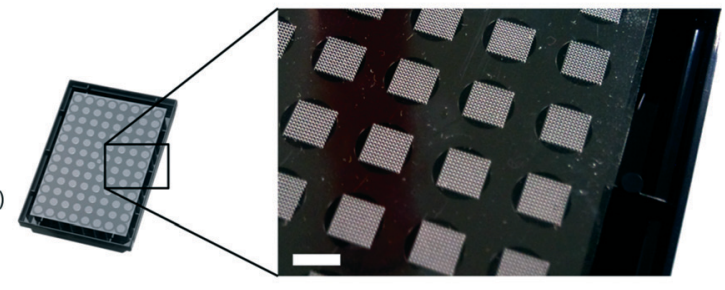

Fig. 1 Fabrication method of thermoformed microwell screening plate. (a) The microwells are fabricated in a $50 \mu \mathrm{m}$ thin COP film through a process of micro negative free-(thermo)forming. Thereby, the heated and softened film is formed into a mould of circular microcavities under high pressure. (b) Micro-thermoforming depth was measured at multiple locations on different COP films. The depth was measured at 5 different locations on the plate. (c) Scanning electron microscopy image of a microwell section depicting its hemispherical geometry. The microwells have a diameter of around $300 \mu \mathrm{m}$ and a depth of approximately $260 \mu \mathrm{m}$. Scale bar: $100 \mu \mathrm{m}$. (d) The micro-thermoformed film was pressure-bonded to the bottomless $96 \mathrm{wp}$ through a punched cytocompatible double-sided tape. (e) Image of the backside of the full thermoformed microwell screening plate, including an enlarged image showing the microwell arrays. Each array corresponds with a single well of the 96 wp. Scale bar: 5 mm. 
a

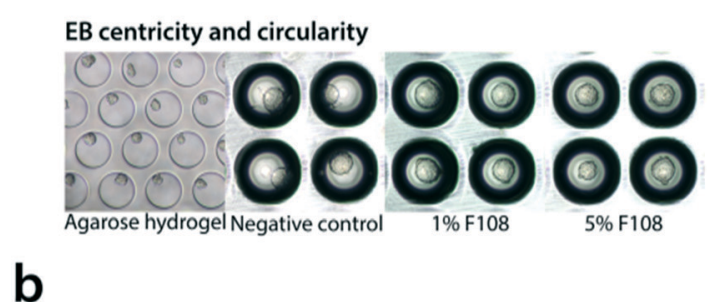

b

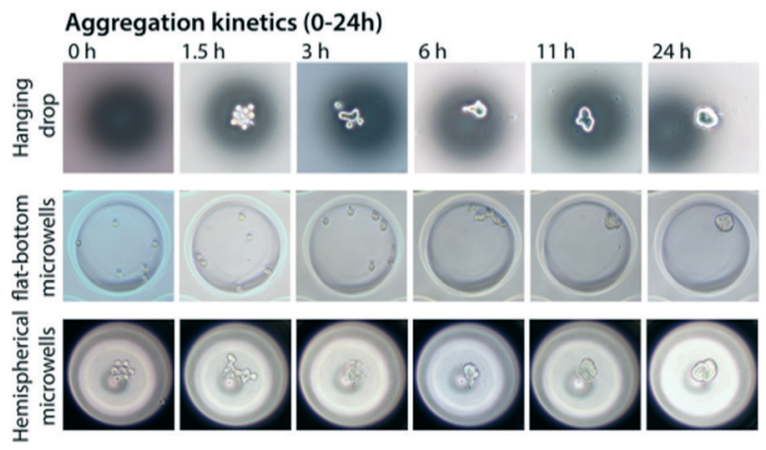

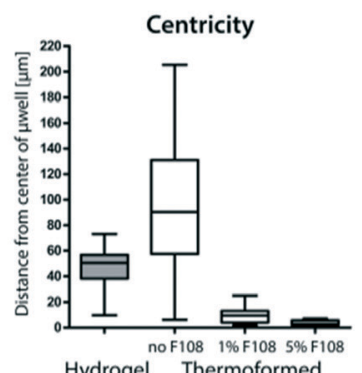

Hydrogel Thermoformed
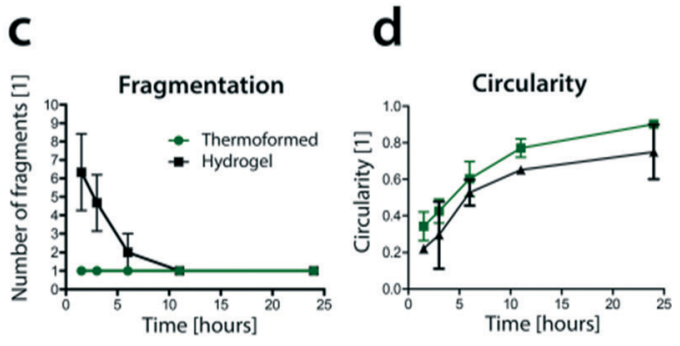

e

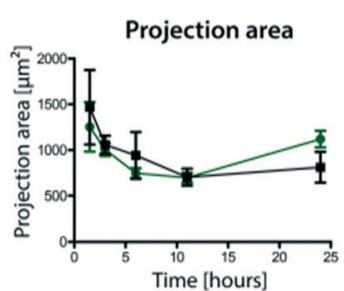

f

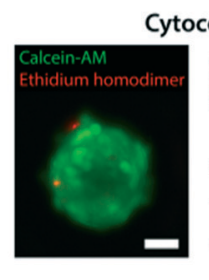

Cytocompatibility

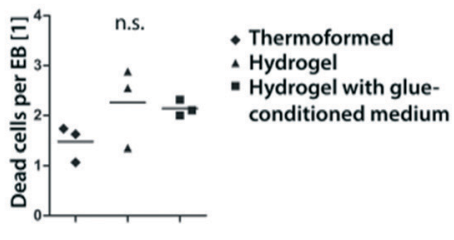

Fig. 2 Embryonic stem cell aggregation kinetics. (a) Thermoformed COP films were pre-treated with 0 (negative control), 1 and $5 \%$ w/v Pluronics F108 in demi-water for 1 hour at $37^{\circ} \mathrm{C}$. EBs from 100 cells per microwell formed within 24 hours of culture. Box-and-whiskers plots displaying the maxima and minima (whiskers) and the median with quartiles (boxes) for the centricity (distance between centre of EB and centre of microwell) and circularity of EBs ( $n=5$ wells). (b) EB aggregation kinetics in thermoformed and hydrogel microwells and in hanging drops displayed in a time series of bright field images. (c) Number of cellular fragments, (d) circularity of the biggest fragments, and (e) total projection area of fragments measured over time ( $n=3$ wells). (f) Viability assay on ES cells using calcein-AM and ethidium homodimer shows dead cells in red and viable cells in green $(n \geq 12)$. 50 cells per microwell were seeded and cultured for 48 hours before stained and imaged. Scale bar: $50 \mu \mathrm{m}$. No statistically significant difference was observed between the conditions (ANOVA), suggesting no toxic effects from the glue.

affected the circularity and centricity of EBs (Fig. 2a negative control). To further reduce cell adhesion and improve formation of EBs, we pre-treated the film with a solution of Pluronics F108. Centricity and circularity of the aggregate increased with increasing concentrations of Pluronics F108 (Fig. 2a). Because differences in centricity and circularity were low between $1 \%$ and $5 \% \mathrm{w} / \mathrm{v}$ Pluronics (Fig. 2a), we chose $1 \%$ as a standard concentration in further experiments.

We compared the round-bottom microwell array, with our state-of-the-art flat-bottom hydrogel microwell array. ${ }^{14}$ The geometry of the thermoformed microwells rapidly concentrated cells in the center, which formed a single aggregate within 1 hour (Fig. 2b and c). In contrast, cells in the flat-bottom microwells formed a single aggregate within 6 to 11 hours (Fig. 2b and c). In addition, EBs centricity and circularity within microwells increased more rapidly in the roundbottom microwells as compared to the flat-bottom microwells (Fig. 2a and d). Within 24 hours EBs in the round-bottom microwells had an average circularity of 0.9 (Fig. 2d) and their size increased from 11 hours of culture onward (Fig. 2e), which suggested cellular proliferation.

After 48 hours of culture, the number of dead cells was similarly low between the two microwell arrays as assessed with calcein AM and ethidium homodimer (Fig. 2f). As a control, we added glue extract from the tape directly to the medium, which did not increase cell death (Fig. 2f). We concluded that the bonding process and the glue did not affect cell viability.

Overall, the data demonstrated that the thermoformed microwell array increased the efficiency of ES cell aggregation (speed, centricity, circularity) as compared to our standard array.

\section{Embryoid body culture}

Obtaining proper statistics in the context of 3D development necessitates a uniform seeding distribution of cells over a high number of replicates. We assessed the distribution of 
cells within microwells by seeding a target number of 50 or 100 cells per microwell. At 72 hours, the distribution of the projection area of EBs (area seen from the top, used as a proxy for EB volume) deviated $12 \%$ from the median for 100 cells and $21 \%$ for 50 cells (Fig. 3a). Results were similar between the two arrays, during the first 48 hours (Fig. 3b). Over time, we observed a drastic increase in EBs size on the thermoformed array (Fig. 3b). Conversely, the flat-bottom hydrogel microwells, having a smaller diameter $(200 \mu \mathrm{m})$, showed a plateau for EB size at approximately $50 \%$ of the projection area of the microwell. The on-chip measurement of the number of cells per microwell is an important feature for such a platform. Here, we observed that the thermoformed array differs from the hydrogel array by allowing on-chip trypsinization and subsequent counting of the number of cells per microwell. Such an on-chip trypsinization and counting assay showed high correlation between the projection area and the number of cells (Fig. 3c).

\section{Screening EBs for PDGFR $\alpha$-H2B-GFP expression using a ki-} nase inhibitor library

Primitive endoderm (PrE) is the first tissue arising from pluripotent stem cells within the inner cell mass of the blastocyst and within EBs. Here, we used this model of differentiation to test the potential of the platform for HTS and HCI. We used an embryonic stem cell line containing a fluorescent nuclear reporter for the genetic activity of the PrE marker PDGFR $\alpha$ (PDGFR $\alpha$-H2B-GFP). ${ }^{21,22}$ We formed EBs by seeding a target number of 13 ES cells per microwell. After aggregation ( 24 hours), we administered a kinase inhibitor library (80 compounds) both at 24 and 72 hours. After 96 hours, we fixed the EBs and assessed differentiation via onchip imaging (Fig. 4a). We quantified the yield of fluorescent reporter expression as the percentage of EBs positive for PDGFR $\alpha$-H2B-GFP (Fig. 4b). PDGFR $\alpha-\mathrm{H} 2 \mathrm{~B}-\mathrm{GFP}^{+}$cells were mostly located in the periphery of EBs as observed by on-chip epifluorescence imaging (Fig. 4c) and on-chip confocal imaging (Fig. 4d). In addition, we quantified morphological parameters, such as the projection area (Fig. 4b) and the form-factor (Fig. 4e), as proxies for size and circularity, respectively. The compounds lethal to cells or autofluorescent were omitted from the analysis (7 compounds). We used Retinoic acid (RA) as a positive control inducing PrE differentiation. ${ }^{23}$ We used the combination of PD325901 (MEK inhibitor) and CHIR-99021 (GSK3-beta kinase inhibitor) as a negative control, due to its assessed function in inhibiting ES cell differentiation. $^{24}$ As expected, indirubin and indirubin-3'monoxime, which also target GSK3-beta kinase, had effects similar to the negative control along the 3 parameters

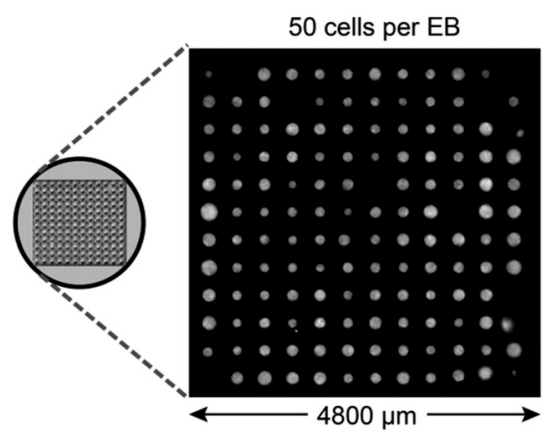

b

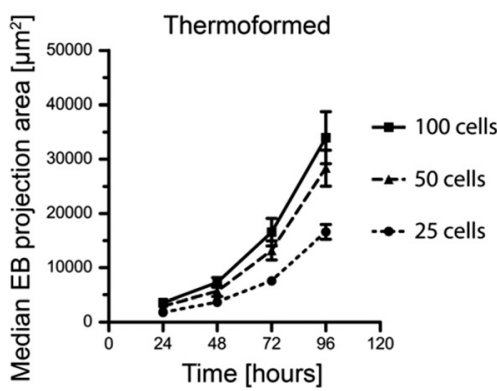

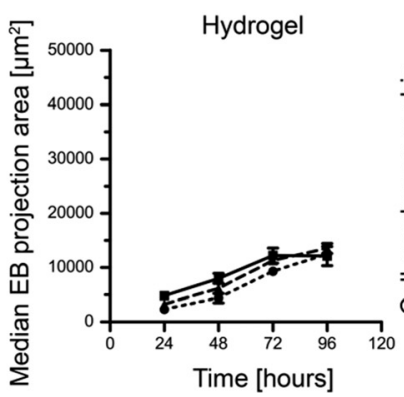

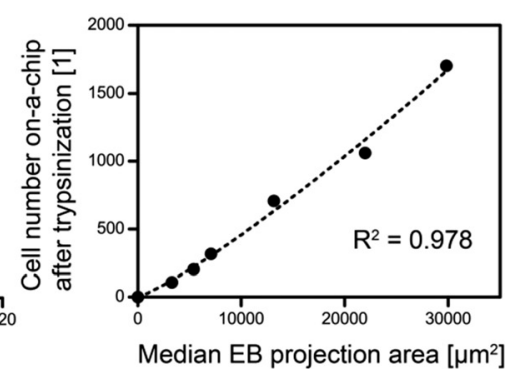

Fig. 3 Embryoid body culture. (a) EBs were cultured for 72 hours, captured using montage imaging, and analysed using Cell Profiler software. The distribution of EB size was plotted for 3 pooled wells, each containing $>100$ EBs. (b) Projection area of EBs as a function of time ( $n=6$ wells, median was taken among $>80$ and $>200$ EBs per well from hydrogel and thermoformed plates, respectively). For comparison, $31400 \mu \mathrm{m}^{2}$ and $\sim 70000 \mu \mathrm{m}^{2}$ equals the projection area of a hydrogel and a thermoformed microwell, respectively. (c) Average number of cells per EB counted after on-chip trypsinization. Data points from different time points (24, 48 and 72 hours) and cell seeding densities (50 and 100 cells per microwell) were plotted together and fitted by a power function, $n=3$ wells per data point. 


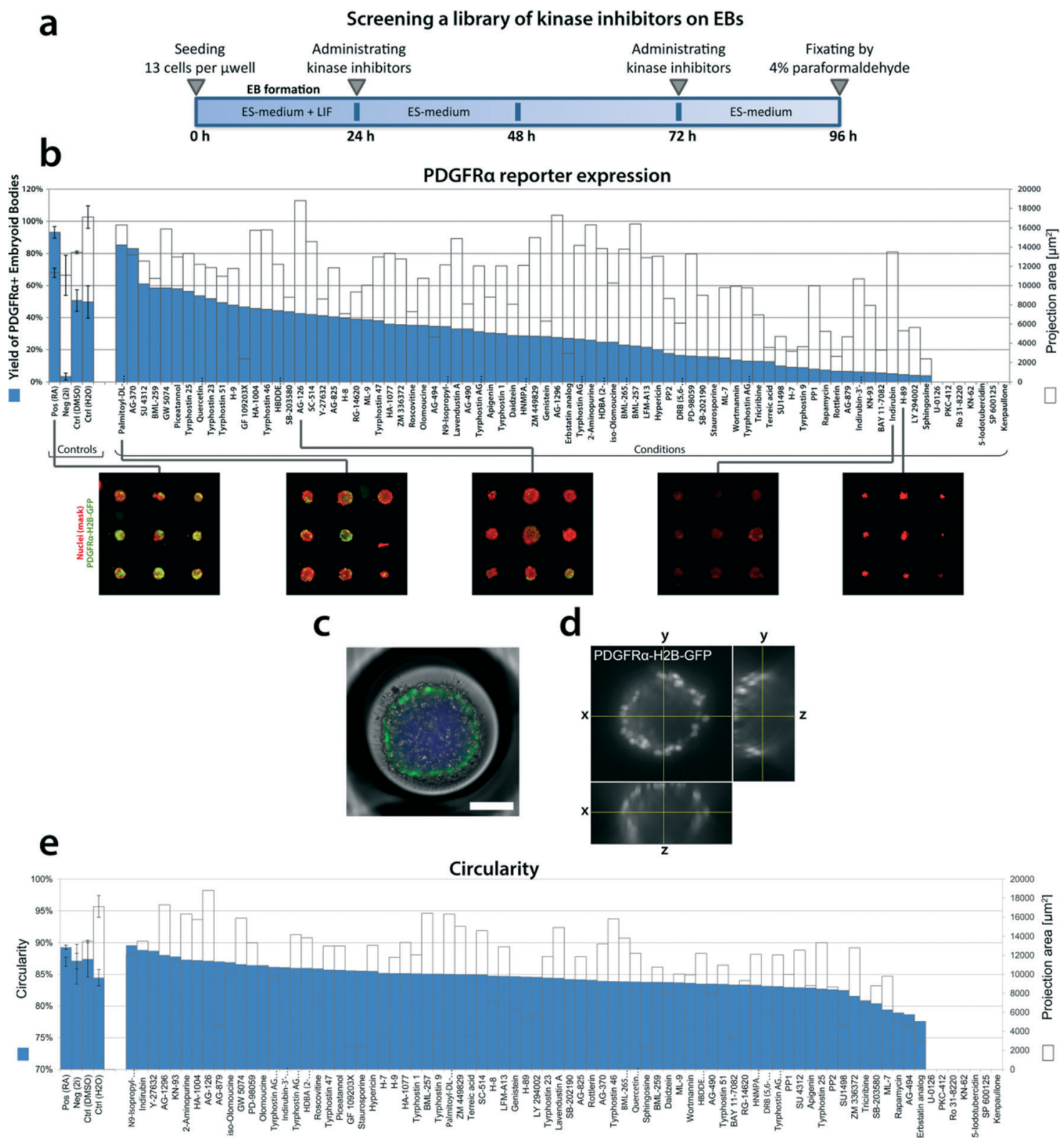

Fig. 4 Kinase inhibitor screening on PDGFR $\alpha-H 2 B-G F P$ expression in EBs. (a) Schematic depicting screening. (b) Yield of EBs positive for PDGFR $\alpha-$ H2B-GFP expression sorted from high to low (blue bars) with the EB size (white bars) including a series of representative fluorescent images ( $n=3$ wells for controls). (c) Overlay of bright field and fluorescent image of a single EB positive for PDGFR $\alpha$-H2B-GFP (20x, blue: DAPI, green: PDGFR $\alpha-$ H2B-GFP). Scale bar: $100 \mu \mathrm{m}$. (d) Orthogonal images acquired via spinning disk confocal microscopy of a single EB including PDGFR $\alpha-H 2 B-G F P+$ cells $(1 \mu \mathrm{m}$ interspacing using a $20 \times$ objective on BD Pathway 435). (e) Circularity of EBs sorted from high to low (blue bars) with the EB size (white bars).

(PDGFR $\alpha$-H2B-GFP expression, projection area and form-factor) (Fig. 4b and d), thus confirming the validity of the assay. The screen revealed that the small molecule palmitoyl-DL-carnitine up-regulates PDGFR $\alpha$ activity. Palmitoyl-DL-carnitine is classified as a protein kinase $\mathrm{C}$ inhibitor, with recurrent function in epithelial transformation, which is essential for PrE differentiation. $^{25}$ Surprisingly, the small molecule AG-370, which was previously classified as a PDGFR $\alpha$ kinase inhibitor, acted as a PDGFR $\alpha$ activator in the context of PrE formation.

\section{Kinase classes}

We further analyzed the data by classifying compounds based on their reported kinase class and along the 3 features (Fig. 5a-c). Fig. 5 shows that compounds with the same predicted kinase-class target clearly have different effects (Fig. 5d). For example, molecules classified as PDGFR $\alpha$ inhibitors either up-regulated or down-regulated PDGFR $\alpha$ activity in EBs (Fig. 5a). Similar effects were observed with compounds classified as PKA, PKC and PI3K inhibitors. This 


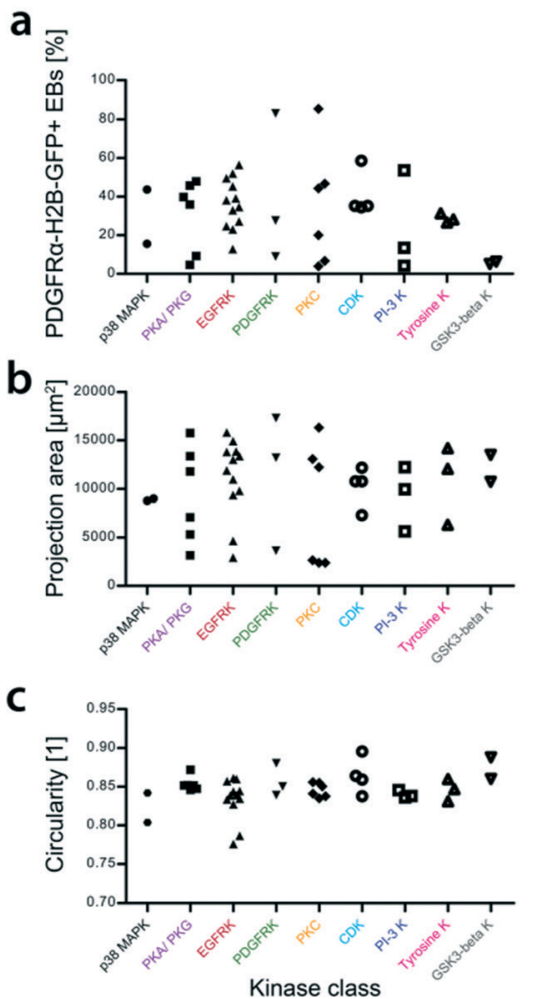

Fig. 5 Kinase inhibitor screening analysis. (a) PDGFR $\alpha$-H2B-GFP expression, (b) projection area of EBs, and (c) circularity of EBs sorted by the most prevalent kinase classes in the library. Depicted in green and red are the pathways currently known to regulate PrE. Depicted in purple and yellow are the novel pathways found to regulate PrE. (d) 3D graph combining data from the previous three graphs and including controls.

observation correlates with studies pointing at the contextdependent and off-target effects of small chemicals ${ }^{26}$ and thus emphasizes the importance of cell type-specific HTS assays. In addition, our classification shows that molecules with the same predicted kinase-class target have similar effects on PDGFR $\alpha$ activity but dissimilar effects on EB size. We propose that this range of phenotypes reflects different biological functions such as the induction of ES cells differentiation into PDGFR $\alpha+$ cells or of proliferation of PDGFR $\alpha$ + cells. Multifactorial on-chip analysis, combining proliferation, morphological and genetic activity might thus yield new insights on the context-dependent functions of small molecules. Overall, these results show that the platform allows for HTS and the rapid monitoring of multiple parameters onchip via automated HCI.

\section{cAMP/PKA activation leads to increased PDGFR $\alpha$ expression}

Negative regulation of the cAMP/PKA pathway, specifically by small molecule H-89, showed inhibition of PDGFR $\alpha$ in EBs (Fig. 4b and 5a). This finding let us to the hypothesis that activation of the cAMP/PKA pathway might increase PDGFR $\alpha$

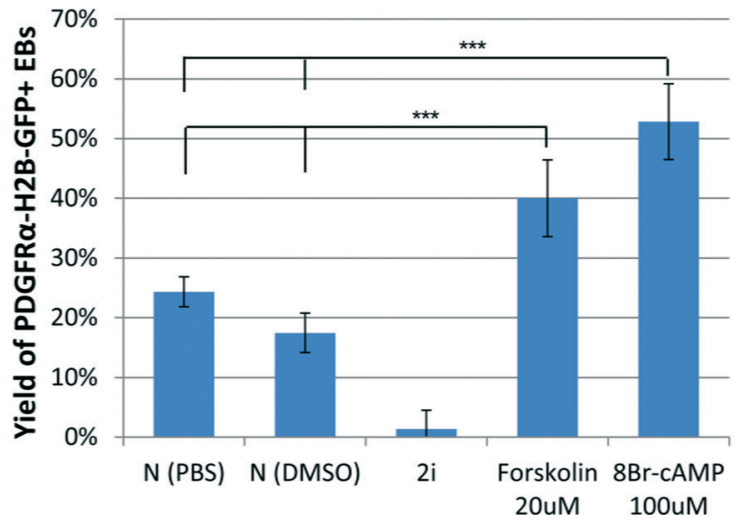

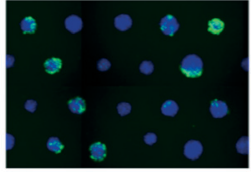

$8 \mathrm{Br}-\mathrm{CAMP} 100 \mu \mathrm{M}$

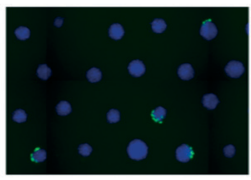

Neutral (PBS)

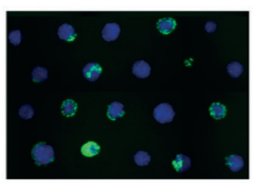

Forskolin $20 \mu \mathrm{M}$

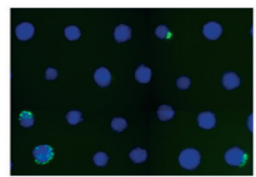

Neutral (DMSO)

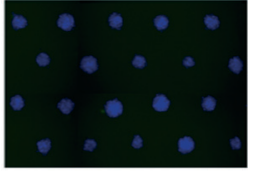

Negative (2i)

Fig. 6 Activators of CAMP/PKA signaling 8Br-CAMP and Forskolin show an upregulation of EBs positive for PDGFRa-H2B-GFP compared to PBS and DMSO controls ( $n=6$ wells, $* * *$ denotes $p<0.001$, ANOVA with Tukey's multiple comparison test). 
expression in EBs. To test this hypothesis, we designed an assay including the small molecules forskolin, an upstream activator of cAMP/PKA signaling, and 8Br-cAMP, a cellpermeable analog of cAMP. Shown in Fig. 6, both compounds significantly increased the yield of PDGFR $\alpha$-H2B-GFP positive EBs (more than 1.6 fold), hereby validating cAMP/PKA signalling as being a novel positive regulator of PDGFR $\alpha$ expression in EBs (Fig. 6).

\section{Discussion}

Using a novel microwell platform, we described the effect of a panel of small molecule kinase inhibitors on EB size, form and gene activity. We describe two small molecules that acted in the primary screen as positive regulators for the reporter gene PDGFR $\alpha$ in the context of PrE differentiation. Negative regulation of the cAMP/PKA pathway, specifically by small molecule H-89, showed inhibition of PDGFR $\alpha$ in EBs. This led us to validate activators of the cAMP/PKA pathway as PDGFR $\alpha$ is a gene involved in early embryonic differentiation of the PrE, from which the visceral yolk sac endoderm develops. The yolk sac is the primary site of hematopoiesis. ${ }^{27}$ As such, the 3D directed differentiation of EBs into PrE might serve as a starting point, for example, for the development of blood cells precursors. ${ }^{28,29}$ More generally, we speculate that platforms allowing for the reproducible, controlled and rapid formation of multiple replicates along with HTS will accelerate the use of organoids as models with greater prediction power for scientific and clinical studies.

In our system, however, the formed EBs are comparatively small to benefit larger organoid models. Also, on-chip imaging problems might occur for cells located in the periphery of biological models that approach the size of the microwells due to internal reflection of light within the curved polymer film. Therefore, developing a range of larger microwells (optionally with a flatter bottom) could aid the imaging quality and support the culture of larger organoid models, such as the kidney. ${ }^{30}$ To preserve a high number of microwells and to augment cell seeding uniformity even further, the squared array of microwells should be extended to cover the full surface area of the wells. For this purpose, costly new metal molds have to be micro-machined, which necessitates a thorough examination of useful sizes.

In micro-thermoforming a thin thermoplastic polymer film is formed within its softened, but still solid, thermoelastic state, which allows for the preservation of previously generated (surface and bulk) modifications of the film, such as topographical imprints of micro- and nanoscale, ${ }^{31}$ and localized cell adhesion domains through patterned UV-irradiation. ${ }^{18,19}$ Accordingly, the microwell screening plate can be tailored with desirable features by premodification of the polymer film. As was previously reported, thermoplastic films can be ion track-etched to yield micropores within microwells. ${ }^{18,32}$ Porous microwells, then in a 3D-Boyden-chamber or Transwell ${ }^{\circledR}$ approach, can potentially function as a biomimetic interface that allows soluble factors to be exchanged, which could be useful to study paracrine signaling between different tissues. We propose that microthermoforming technology opens new possibilities for the creation of more controlled and complex in vitro microenvironments.

\section{Conclusions}

We showed a microwell platform, fabricated by assembling micro-thermoformed films with standard 96-well culture plates, whose format is compatible with HTS and HCI systems. The platform increases the controlled manifold formation and chemical exposure of EBs along with the acquisition of features directly on-chip, such as cellular proliferation via direct trypsinization/counting and aggregate morphology and gene activity via automated microscopy. We validated the platform for HTS using a library of small molecule kinase inhibitors and observed the functional specificity of small molecules in the context of PrE differentiation. The finding of cAMP/PKA as a novel pathway in PrE differentiation shows that this platform is suitable for the unbiased identification of compounds directing tissue development. We propose that this approach will benefit to the systematic production of cells, tissues and organs with an impact in pharmacology and regenerative medicine.

\section{Materials and methods}

\section{Thermoplastic films}

Cyclic olefin copolymer (COP) films had a thickness of $50 \mu \mathrm{m}$ and were obtained from two different suppliers: 'Zeonor mcs foil 051' films were obtained from microfluidic ChipShop GmbH and 'ZeonorFilm ZF14-050, Zeonex' films were obtained from Sidaplax. This polymer has a glass transition temperature of $c a .136^{\circ} \mathrm{C}$.

\section{Mold fabrication and microthermoforming}

The wellplate-sized brass mold containing the microholes was fabricated by mechanical micromachining (microdrilling). Then, the cyclic olefin polymer film was clamped between the brass mold and a brass counterplate. Microthermoforming was performed by heating the film followed by applying a differential pressure through an integrated channel within the counterplate, which stretched the film onto the micromachined mold. After cooling down the microthermoformed COP film was released.

\section{Assembly of the plate}

3M VHB acrylic elastomer tape, a biocompatible double-sided tape, was punched with holes using a custom-made punching device. Then, this tape was used to adhere the COP film containing the microwell arrays to a bottom-less 96-well plate. A force of about $30 \mathrm{~N}$ was applied at room temperature for 12 hours on top of the assembly for bonding. Sterilization was done by immersing the plate in $70 \% \mathrm{v} / \mathrm{v}$ ethanol in demi- 
water for 15 minutes. Full wetting of the microwells was achieved by shortly applying a vacuum.

\section{Cell repellence}

A solution of 0,1 and 5\% w/v of Pluronics F108 (Sigma-Aldrich) was prepared in sterile demi-water, dispensed into the thermoformed microwell array plate as $100 \mu \mathrm{L}$ per well and incubated overnight at $37^{\circ} \mathrm{C}$. The Pluronics solution was gently washed out from the wells using sterile demi-water before cells were seeded into the microwells.

\section{Cell culture and reagents}

Mouse ES cells were expanded on a feeder layer of mouse embryonic fibroblasts (mEF) in ES medium containing: Dulbecco's Modified Eagle's Medium High Glucose (Life Technologies) supplemented with $10 \%$ fetal bovine serum (FBS, Greiner), $4 \mathrm{mM}$ Glutamax (Life Technologies), $100 \mathrm{U}$ $\mathrm{mL}^{-1}$ penicillin (Life Technologies), $100 \mathrm{mg} \mathrm{mL}^{-1}$ streptomycin (Life Technologies), $10 \mathrm{mM}$ non-essential amino acids (Life Technologies), and freshly supplemented with $0.05 \mathrm{mM}$ 2-mercaptoethanol (Life technologies), $1000 \mathrm{U} \mathrm{mL}^{-1}$ leukemia inhibitory factor (LIF, Life Technologies), $3 \mu \mathrm{M}$ CHIR99021 (GSK3 $\beta$ inhibitor, Axon Medchem) and $1 \mu \mathrm{M}$ PD0325901 (MEK/ERK inhibitor, Sigma Aldrich). EBs were formed using a mouse ES cell line comprising a PDGFR $\alpha^{\text {H2B-GFP/+ }}$ knock-in allele (a histone $\mathrm{H} 2 \mathrm{~B}-\mathrm{GFP}$ fusion protein reporter under the control of PDGFR $\alpha$ regulatory elements ${ }^{22}$ ).

\section{Kinase inhibitor screening}

A kinase inhibitor library V2.2 (80 chemicals reconstituted at $10 \mathrm{mM}$ in DMSO, Enzo Life Sciences) was used to screen for molecules that modulate H2B-GFP reporter activity in EBs formed using a mouse ES cell line comprising a PDGFR $\alpha^{\mathrm{H} 2 \mathrm{~B}-\mathrm{GFP} /+}$ knock-in allele. A target number of $1872 \mathrm{ES}$ cells was seeded per well, which corresponds to 13 ES cells per microwell. ES cells were allowed to aggregate over 24 hours in $250 \mu \mathrm{L}$ per well of ES-medium including $10 \%$ FBS (selected batch for ES culture, Greiner) and supplemented with $1 \mu \mathrm{g} \quad \mathrm{mL}^{-1}$ LIF (Life Technologies) and $50 \mu \mathrm{M}$ $\beta$-mercaptoethanol (Sigma-Aldrich). After 24 hours and 72 hours $200 \mu \mathrm{L}$ of medium was refreshed with ES medium including 10\% FBS and supplemented with $50 \mu \mathrm{M}$ $\beta$-mercaptoethanol, and the kinase inhibitor compounds were administered in a working concentration of $20 \mu \mathrm{M}$. As a negative control $2 \mathrm{i}$ conditions were applied (combination of 1 $\mu \mathrm{M}$ PD325901, $3 \mu \mathrm{M}$ CHIR-99021 and $1 \mu \mathrm{g} \mathrm{mL}^{-1}$ LIF). As a positive controls $1 \mu \mathrm{M}$ RA was used. During embryonic development the PrE is firmly established after 96 hours, ${ }^{22}$ thus after 96 hours of culture EBs were fixated using $4 \% \mathrm{w} / \mathrm{v}$ paraformaldehyde, washed in PBS, stained with $100 \mu \mathrm{L}$ of $0.7 \mu \mathrm{g}$ $\mathrm{mL}^{-1}$ DAPI solution (Sigma Aldrich, D9542), washed in PBS and imaged on-chip using the BD Pathway 435 and its imagemontage function in combination with a $10 \times$ objective. Phenotypical data were acquired from montaged images using a custom-made pipeline in CellProfiler2.0 (Broad Institute). ${ }^{33}$

\section{Measurements}

For the ES cell aggregation kinetics the projection area, circularity and fragment number were measured using Image J (http://rsbweb.nih.gov/ij/). Circularity measured in Image J and CellProfiler (circularity equals form factor) was calculated as $4 \pi^{*}[$ area $] /\left([\text { perimeter }]^{2}\right)$. Background intensity was removed from all images, except the PDGFR $\alpha$ images, by subtracting the average overall intensity from the whole image.

\section{Acknowledgements}

EJV gratefully acknowledge the Netherlands Institute for Regenerative Medicine program (NIRM). NCR gratefully acknowledge the Translational Adult Stem Cell program (ZonMW). This work was carried out with the technical support of the Karlsruhe Nano Micro Facility (KNMF, www.kit. edu/knmf), a Helmholtz Research Infrastructure at Karlsruhe Institute of Technology (KIT, www.kit.edu), and of European Research Infrastructure for multimaterial micro and nano fabrication and characterization (EUMINAfab). We also want to express our gratitude to Anna-Katerina Hadjantonakis for providing the PDGFR $\alpha^{\mathrm{H} 2 \mathrm{~B}-\mathrm{GFP} /+}$ embryonic stem cell line.

\section{References}

1 M. A. Schwartz and C. S. Chen, Science, 2013, 339, 402-404.

2 K. W. McCracken, E. M. Cata, C. M. Crawford, K. L. Sinagoga, M. Schumacher, B. E. Rockich, Y. H. Tsai, C. N. Mayhew, J. R. Spence, Y. Zavros and J. M. Wells, Nature, 2014, 516, 400-404.

3 M. Eiraku, N. Takata, H. Ishibashi, M. Kawada, E. Sakakura, S. Okuda, K. Sekiguchi, T. Adachi and Y. Sasai, Nature, 2011, 472, 51-56.

4 M. A. Lancaster, M. Renner, C. A. Martin, D. Wenzel, L. S. Bicknell, M. E. Hurles, T. Homfray, J. M. Penninger, A. P. Jackson and J. A. Knoblich, Nature, 2013, 501, 373-379.

5 A. M. Pasca, S. A. Sloan, L. E. Clarke, Y. Tian, C. D. Makinson, N. Huber, C. H. Kim, J. Y. Park, N. A. O'Rourke, K. D. Nguyen, S. J. Smith, J. R. Huguenard, D. H. Geschwind, B. A. Barres and S. P. Pasca, Nat. Methods, 2015, 12, 671-678.

6 E. R. Shamir and A. J. Ewald, Nat. Rev. Mol. Cell Biol., 2014, 15, 647-664.

7 M. van de Wetering, H. E. Francies, J. M. Francis, G. Bounova, F. Iorio, A. Pronk, W. van Houdt, J. van Gorp, A. Taylor-Weiner, L. Kester, A. McLaren-Douglas, J. Blokker, S. Jaksani, S. Bartfeld, R. Volckman, P. van Sluis, V. S. Li, S. Seepo, C. Sekhar Pedamallu, K. Cibulskis, S. L. Carter, A. McKenna, M. S. Lawrence, L. Lichtenstein, C. Stewart, J. Koster, R. Versteeg, A. van Oudenaarden, J. Saez-Rodriguez, R. G. Vries, G. Getz, L. Wessels, M. R. Stratton, U. McDermott, M. Meyerson, M. J. Garnett and H. Clevers, Cell, 2015, 161, 933-945.

8 A. Sridhar, H. L. de Boer, A. van den Berg and S. Le Gac, PLoS One, 2014, 9, e93618. 
9 B. Altmann, R. Ahrens, A. Welle, H. Dinglreiter, M. Schneider and A. Schober, Biomed. Microdevices, 2012, 14, 291-301.

10 Y. Y. Choi, B. G. Chung, D. H. Lee, A. Khademhosseini, J. H. Kim and S. H. Lee, Biomaterials, 2010, 31, 4296-4303.

11 K. Kwapiszewska, A. Michalczuk, M. Rybka, R. Kwapiszewski and Z. Brzozka, Lab Chip, 2014, 14, 2096-2104.

12 B. R. Desroches, P. Zhang, B. R. Choi, M. E. King, A. E. Maldonado, W. Li, A. Rago, G. Liu, N. Nath, K. M. Hartmann, B. Yang, G. Koren, J. R. Morgan and U. Mende, Am. J. Physiol., 2012, 302, H2031-H2042.

13 K. R. Stevens, M. D. Ungrin, R. E. Schwartz, S. Ng, B. Carvalho, K. S. Christine, R. R. Chaturvedi, C. Y. Li, P. W. Zandstra, C. S. Chen and S. N. Bhatia, Nat. Commun., 2013, 4, 1847.

14 N. C. Rivron, E. J. Vrij, J. Rouwkema, S. Le Gac, A. van den Berg, R. K. Truckenmuller and C. A. van Blitterswijk, Proc. Natl. Acad. Sci. U. S. A., 2012, 109, 6886-6891.

15 M. Buitinga, R. Truckenmuller, M. A. Engelse, L. Moroni, H. W. Ten Hoopen, C. A. van Blitterswijk, E. J. de Koning, A. A. van Apeldoorn and M. Karperien, PLoS One, 2013, 8, e64772.

16 R. Truckenmuller, S. Giselbrecht, N. Rivron, E. Gottwald, V. Saile, A. van den Berg, M. Wessling and C. van Blitterswijk, Adv. Mater., 2011, 23, 1311-1329.

17 E. Gottwald, S. Giselbrecht, C. Augspurger, B. Lahni, N. Dambrowsky, R. Truckenmuller, V. Piotter, T. Gietzelt, O. Wendt, W. Pfleging, A. Welle, A. Rolletschek, A. M. Wobus and K. F. Weibezahn, Lab Chip, 2007, 7, 777-785.

18 S. Giselbrecht, T. Gietzelt, E. Gottwald, C. Trautmann, R. Truckenmuller, K. F. Weibezahn and A. Welle, Biomed. Microdevices, 2006, 8, 191-199.

19 S. Giselbrecht, T. Gietzelt, E. Gottwald, A. E. Guber, C. Trautmann, R. Truckenmuller and K. F. Weibezahn, IEE Proc.: Nanobiotechnol., 2004, 151, 151-157.
20 W. D. Niles and P. J. Coassin, Assay Drug Dev. Technol., 2008, 6, 577-590.

21 J. Artus, J. J. Panthier and A. K. Hadjantonakis, Development, 2010, 137, 3361-3372.

22 B. Plusa, A. Piliszek, S. Frankenberg, J. Artus and A. K. Hadjantonakis, Development, 2008, 135, 3081-3091.

23 M. P. Stavridis, B. J. Collins and K. G. Storey, Development, 2010, 137, 881-890.

24 Q. L. Ying, J. Wray, J. Nichols, L. Batlle-Morera, B. Doble, J. Woodgett, P. Cohen and A. Smith, Nature, 2008, 453, 519-523.

25 N. Saiz, J. B. Grabarek, N. Sabherwal, N. Papalopulu and B. Plusa, Development, 2013, 140, 4311-4322.

26 J. C. Uitdehaag, F. Verkaar, H. Alwan, J. de Man, R. C. Buijsman and G. J. Zaman, Br. J. Pharmacol., 2012, 166, 858-876.

27 J. F. Toles, D. H. Chui, L. W. Belbeck, E. Starr and J. E. Barker, Proc. Natl. Acad. Sci. U. S. A., 1989, 86, 7456-7459.

28 E. T. Zambidis, B. Peault, T. S. Park, F. Bunz and C. I. Civin, Blood, 2005, 106, 860-870.

29 S. M. Dang, M. Kyba, R. Perlingeiro, G. Q. Daley and P. W. Zandstra, Biotechnol. Bioeng., 2002, 78, 442-453.

30 M. Takasato, P. X. Er, M. Becroft, J. M. Vanslambrouck, E. G. Stanley, A. G. Elefanty and M. H. Little, Nat. Cell Biol., 2014, 16, 118-126.

31 R. Truckenmuller, S. Giselbrecht, M. Escalante-Marun, M. Groenendijk, B. Papenburg, N. Rivron, H. Unadkat, V. Saile, V. Subramaniam, A. van den Berg, C. van Blitterswijk, M. Wessling, J. de Boer and D. Stamatialis, Biomed. Microdevices, 2012, 14, 95-107.

32 R. Truckenmuller, S. Giselbrecht, C. van Blitterswijk, N. Dambrowsky, E. Gottwald, T. Mappes, A. Rolletschek, V. Saile, C. Trautmann, K. F. Weibezahn and A. Welle, Lab Chip, 2008, 8, 1570-1579.

33 M. R. Lamprecht, D. M. Sabatini and A. E. Carpenter, BioTechniques, 2007, 42, 71-75. 